UDC 94(495).01

Submitted: 22.03 .2017

LBC 63.3(0)4

Accepted: 28.09 .2017

\title{
JUSTINIAN I'S CHURCH BUILDING BY THE DATA OF HIS NOVELS
}

\author{
Yuriy A. Kreydun \\ Barnaul Theological College, Barnaul, Russian Federation \\ Vadim V. Serov ${ }^{1}$ \\ Altay Institute of Economics, Branch of Saint Petersburg University \\ of Management Technologies and Economics, Barnaul, Russian Federation
}

\begin{abstract}
The new publication carries on the study with theme of the Justinian's I building activity. There is the legislative material of the period 535-546 selected as the research object. An analysis of data of the Justinianic novels and edicts displays some interesting things, which do partly correct a certain modern notions of this object. At the same time, the legislative data corroborated the known from other sources fact of intensive church building under Justinian the Great. The well-known prevailing role of the private builder in the same time did receive the supplementary confirmation as well. But Justinian I was not a big private builder of churches, as the literary historical sources try to demonstrate. This emperor is mentioned in his novels in connection with the building of monasteries. It's scholar knowledge that Justinian was working out the standards in the sphere of the religious building. However, full regulation of the building process didn't take place under his rule: just separate norms have arisen then, which concerned mainly the proprietors' rights and duties, and as well indirectly as the volume of church building. Consequently, Justinian the Emperor did not only build many religious edifices, but limited private building too. Finally, the aforesaid witnesses that he didn't have any program of church building in the Empire, and he didn't waste state financial means for its realization.
\end{abstract}

Key words: Justinian the First, church building, legislation, novels, religious policy.

Citation. Kreydun Yu.A., Serov V.V. Justinian I's Church Building by the Data of His Novels. Vestnik Volgogradskogo gosudarstvennogo universiteta. Seriya 4, Istoriya. Regionovedenie. Mezhdunarodnye otnosheniya [Science Journal of Volgograd State University. History. Area Studies. International Relations], 2017, vol. 22, no. 5, pp. 27-37 (in Russian). DOI: https://doi.org/10.15688/jvolsu4.2017.5.3

УДК 94(495).01

ББК $63.3(0) 4$

Дата поступления статьи: 22.03.2017

Дата принятия статьи: 28.09.2017

\section{ЦЕРКОВНОЕ СТРОИТЕЛЬСТВО ЮСТИНИАНА І ПО ДАННЫМ ИЗДАННЫХ ИМ НОВЕЛЛ}

\author{
Юрий Александрович Крейдун
}

Барнаульская духовная семинария, г. Барнаул, Российская Федерация

\section{Вадим Валентинович Серов ${ }^{1}$}

\section{Алтайский институт экономики (филиал) Санкт-Петербургского университета технологий управления} и экономики, г. Барнаул, Российская Федерация

Аннотация. В законодательстве начального периода правления Юстиниана I (527-534) обнаруживается интерес законодателя к сфере строительства религиозных объектов, проявившийся в неоднократном, но поверхностном упоминании данного явления. В условиях активной церковной политики, а также усилий императора по упорядочению ряда сегментов правовых отношений в государстве такой интерес должен был привести со временем к разработке комплекса норм, которые регулировали бы процесс возведения и последующего разнообразного обслуживания столь специфических и важных для империи сооружений. Однако 


\section{ВИЗАНТИЙСКОЕ ПРАВОСЛАВИЕ}

этого в полной мере не произошло. Как показывают данные законодательства после 534 г., Юстиниан обратил более пристальное внимание лишь на две проблемы сферы церковного строительства - бесконтрольность весьма энергичной частной инициативы и слабая ответственность ктиторов в деле снабжения вновь отстроенных церквей всем для них необходимым. Сам процесс возведения религиозных домов императора не интересовал. Следовательно, Юстиниан I не только не был активным участником создания в стране сети православных учреждений, но и ограничивал их строительство частными лицами.

Ключевые слова: Юстиниан, церковное строительство, законодательство, новеллы, религиозная политика.

Цитирование. Крейдун Ю. А., Серов В. В. Церковное строительство Юстиниана I по данным изданных им новелл // Вестник Волгоградского государственного университета. Серия 4, История. Регионоведение. Международные отношения. - 2017. - Т. 22, № 5. - С. 27-37. - DOI: https://doi.org/10.15688/jvolsu4.2017.5.3

В предыдущей публикации о строительстве церквей в юстиниановскую эпоху рассмотренный законодательный материал позволил сформулировать предварительный вывод о весьма слабом участии государства и лично императора в осуществлении, как принято полагать, принципиально важной для христианской империи задачи увеличения числа православных учреждений на ее территории [7]. Незначительное в общей массе религиозных постановлений количество конституций 527-534 гг., упоминавших собственно строительство церквей и прочих богоугодных заведений, возможно, и обозначило собой принципиально новое отношение позднеантичного государства к институту религиозного ктиторства [6, с. 89-90], однако их содержание, как и само появление в юридическом пространстве ранневизантийского социума, а также бо́льшая, чем прежде, фокусировка на сфере церковного строительства позволили лишь робко надеяться на то, что едва обозначенное ими направление в постклассическом римском праве оформится в недалеком будущем в отдельную отрасль, которая регулировала бы и детализировала как сам процесс возведения столь специфических построек («божьих домов»), так и правовые взаимоотношения участников данного процесса. Позаботиться об этом должен был император Юстиниан I, которому традиционно приписывается и небывалая строительная активность, и активная церковная политика, поскольку новая область нормотворчества сообщала ему дополнительную возможность реализовать имперские амбиции через реформирование сферы непосредственных взаимных отношений церкви, общества и государства.
В настоящей статье на основе анализа законодательного материала 535-565 гг. разрешаются следующие вопросы: продвинулось ли религиозное строительство при Юстиниане по пути приобретения свойств отдельной отрасли производства и сферы права? Насколько значительным являлось строительство религиозных христианских объектов во второй трети VI в.? Наконец, какова действительная роль Юстиниана в умножении церквей и монастырей в Империи?

Обзор эдиктов и новелл Юстиниана I (для чего использовалось стереотипное издание: [10]) выявил несколько интересных для обозначенной темы фрагментов, которые в переводе выглядят так:

Nov. Just. 3: Tот же василевс <Юстиниан $>$ - Епифанию, архиепископу этого иарского Города и вселенскому патриарху,

«Чтобы было определено количество клириков священнейшей Великой церкви и прочих святейших церквей счастливейшего Города».

$<$ Pr. $>$. $<\ldots>$ Итак $<\ldots .>$, мы открыли, что каждый из тех, кто строил священнейшие церкви в этом счастливейшем Городе, задумывался не только о постройке, но и чтобы от себя дать созданным уважаемым <домам> достаточные расходы, и определял, сколько было бы приемлемо назначить для каждой церкви пресвитеров, и сколько - диаконов мужского полу, а также женщин, и сколько - иподиаконов, и, опять же, певцов, а также и чтецов, и ризничих; и сверх того, определял и расходы <на> молельню, и передавал собственные достаточные расходы тем, кого сам назначил, а если кто и увеличивал $<$ их $>$ множество, то это совершенно никак не расширяло достаточных <затрат> на <изначально опре- 
деленное> число клириков. И такие правила оставались вплоть до последнего времени; и пока было так, они твердо соблюдались домами священнейших церквей, которые были достаточны. И если любезные Богу епископы, всегда учитывающие чьи-либо просьбы, увеличивают количество назначений, то множество расходов возрастает до великой безмерности, кредиторы же - отовсюду, и проценты, и все новые, $<\ldots>$, а $<$ сверх того - и> отчуждения с принуждением и вопреки законам, и непристойные дела, и несопряженность с собственным имуществом; <пусть же будет так,> чтобы из-за этой чрезмерности ни поместья, ни пригородные <хозяйства> не доставались ипотекам и залогам, и вследствие этого не появлялись кредиторы, и <не > доходили до крайней бедности, и были достаточны давать прибыль своим служащим, а дело $<$ чтобы не> вставало на несчастливейший из всех путь, по которому все имущества уходят к кредиторам. $<\ldots>$

Дано в 17-й день перед календами апреля в консульство светлейшего мужа Велизария <то есть 16 марта 535 г.>.

(Здесь обозначена проблема содержания храмов. Крупные столичные храмы, построенные ктиторами, возможно, не имели общин верующих, которые регулярно жертвовали бы на содержание собственно здания храма и причта. В связи с этим вставала проблема поиска средств на эти цели. По-видимому, одним из способов решения материальных затруднений были кредиты: император несколько раз указывает на неприемлемость ситуации, когда храм оказывался неплатежеспособным и имущество должно было передаваться кредиторам в обеспечение займа. Во избежание данной ситуации строители (ктиторы) должны были озаботиться выделением средств на содержание храмов и определять размер штата клириков.)

Nov. Just. 5: Автократор Юстиниан Август - Епифанию, святейшему и блаженнейшему архиепископу этого иарского Города и вселенскому патриарху,

«О монастырях, монахах и игуменах» (фрагменты в переводе К.А. Максимовича: [3, с. 40, 43-44]).

$$
<\ldots>
$$

I. Прежде всего прочего следует сказать о том, что во всякое время и во всякой земле нашей империи если кто-либо захочет основать святой монастырь, то он не вправе этого делать, пока не пригласит боголюбивейшего епископа тех мест, и тот, с молитвой воздев руки к небесам, посвятит то место Богу, водрузив на нем символ нашего спасения <...> Таким образом, заложив некое благое и достойное основание, <можно> начинать строительство. Таковым да будет благочестивое начало создания святых монастырей.

$<\ldots>$

IV. Если же кто-либо, посвятив себя $<$ Богу $>$ и приняв $<$ монашеский $>$ образ, пожелает впоследствии оставить монастырь и жить как частное лицо, $<\ldots>$ то имущество, которым он владел при вступлении в монастырь, да пребудет в собственности монастыря, и вообще ничего из этого он не сможет получить обратно.

$<\ldots>$

Дано в Константинополе, в 16-й день перед календами апреля, в консульство светлейшего мужа Велизария <то есть 17 марта 535 г.>.

(Данный фрагмент говорит о сакрализации монастырей. Начало строительства может быть положено не иначе, как после молитвы епископа и водружения креста на этом месте. Обратим внимание на то, что от епископа не испрашивается формальное разрешение на учреждение обители, а личное благословение по особому чину, который будет сформирован позднее в христианской литургике. Обращает на себя внимание еще одна деталь. Освятить место под строительство может не всякий епископ, а епископ именно тех мест. Здесь мы не можем не заметить влияния на тексты новелл Юстиниана канонических правил Церкви. Сакрализацией церковного имущества объясняется и невозможность изъятия обратно имущества, пожертвованного или переданного в монастырское владение.)

Nov. Just. 6: Toт же василевс - Епифанию, святейтему архиепископу этого иарского Города и вселенскому патриарху,

«О том, как следует рукополагать епископов, пресвитеров и диаконов - мужчин и женщин, и каковы наказания для тех, кто на- 


\section{ВИЗАНТИЙСКОЕ ПРАВОСЛАВИЕ}

рушает букву данного закона» (фрагмент в переводе К.А. Максимовича: [5, с. 41-42]). $<\ldots>$

VIII. $<\ldots>$ Относительно же всех мест, находящихся вне <столицы>, повелеваем: если кто-либо с самого начала основал и построил церковь, установил число клириков и определил соответствующий объем расходов, то не следует поставлять кого-либо в эту церковь прежде, чем его содержание будет учтено в изначально установленном составе <клира > Если же этого не произошло, то пусть городская <соборная> церковь снабжает средствами и сама себя, и другие церкви - тогда эти последние не будут по причине, например, неких личных симпатий или благодарности произвольно увеличивать число своих клириков и отягощать < главную церковь> расходами (ибо это неблагочестиво и недостойно иереев); но от того, что дает Господь Бог, от этого она по возможности должна уделять, или же пусть соблюдает прежний обычай, не допуская никаких нововведений. В свою очередь, боголюбивейшие патриархи и митрополиты должны осуществлять за этим надзор и разрешать ранее поставленным клирикам $<$ сохранять $>$ свою должность, однако соразмерять это с возможностями каждой церкви, и таким образом и сами преосвященные патриархи пусть руководят подвластными церквами, и митрополиты по указанию преосвященных патриархов пусть делают то же самое - направляют всех прочих подчиненных им епископов к соблюдению указанной соразмерности и не стремятся совершать хиротонии, $<$ приводящие > к превышению расходов. Ведь известно, сколь много святейших церквей пришли в упадок именно из-за таких необдуманных поставлений в клир и других трат; некоторые из них, хоть и с трудом, нам удалось спасти, тогда как другие еще изнемогают от тягот, будучи не в состоянии выбраться из бедственного положения. Так пусть же позаботятся об этом святейшие патриархи, митрополиты и прочие боголюбивейшие епископы, чтобы и мы, узнавая от них о происходящем, благосклонно отнеслись к ним, поскольку они показали, что наш >записанный> словами закон претворяется в реальные дела.

$<\ldots>$

Дано в Константинополе, в 17-й день перед календами апреля, в консульство светлейшего мужа Велизария <то есть 16 марта 535 г.>.

(Данная новелла носит характер внушения епископам, в компетенции которых находились посвящения новых членов клира. Юстиниан, имея в виду случаи разорения храмов из-за необдуманного увеличения рукоположенных священнослужителей, предписывает соизмерять штат духовенства в каждом храме с финансовыми возможностями храмов, то есть их реальными доходами. Доход храма складывался из регулярного финансирования ктиторов, сборов прихожан и прочих взносов. Ктиторы должны были заботиться о содержании храмов, но, вместе с тем, епископы, поставляющие клириков, не могли требовать увеличения пожертвований для содержания большего штата духовенства, чем это было обозначено изначально. Если епископы все же осуществляли новые рукоположения и увеличивали штаты клириков, то дополнительные расходы должны были покрываться из доходов соборных церквей, иными словами, - за счет епархии, поскольку доходы соборных храмов составляли основу бюджета епархии. Наблюдение за согласованностью новых рукоположений по решению местных епископов с реальными бюджетами храмов Юстиниан возлагает на патриархов и митрополитов, которые в административном плане влияли на местных епископов.)

Nov. Just. 57: Tот же василевс - Мене, святейшему архиепископу этого иарского Города и вселенскому патриарху,

«О клириках, которые брошены своей церковью, и о тех, кто возводят священные дома».

$<\ldots>$

II. Однако мы определяем также в честь и уважение твоего статуса так: если кто-то, кто выстроил церковь или даже предоставляет кормление исполняющим в ней службы, пожелает поставить в ней каких-либо клириков, то нет ему разрешения приводить к твоему благочестию тех, кого он желает по своей воле, поскольку они назначаются без исследования и испытания; но <пусть> приведенные испытываются твоей святостью, и по решению и твоему, и того, кто всегда управлял священническим местом, на избрание 
рекомендуются те, кто удобны и твоему блаженству, и твоим преемникам, и явно достойны служения Богу; чтобы таинства Бога не осквернялись (что запрещено святыми изречениями), но чтобы они проводились добродетельно, добросовестно и набожно, поскольку они должны быть целомудренными, и искренними, и внушающими трепет.

$<$ Ер.> Следовательно, мы определяем, чтобы твое блаженство вечно охраняло тех, которые нам нравятся и провозглашены этим священным законом, которые знают, что для нас заботы о тех, кто приносят пользу святейшим церквам, не менее ценны, чем сама жизнь.

Дано в Константинополе, в 15-й день перед календами ноября, в 11-й год императора господина намего Юстиниана Августа, во 2-й год после консульства Велизария <то есть 18 октября 537 г.>.

Nov. Just. 67: Tот же василевс - Мене, святейшему и блаженнейшему вселенскому архиепископу и nатриарху,

«Чтобы никто не строил молельню вопреки воле епископа, и чтобы он прежде определил тех, кто соответствуют <этому> делу

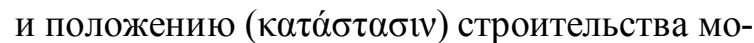
лельни, и чтобы епископы помогали своим церквам, и об отчуждении недвижимых церковных имуществ».

$<\operatorname{Pr}$. Т Так как мы во многих законах охватили $<$ те вопросы $>$, что имеют отношение к священнейшим церквам, <то также> предусматриваем и иные, что в изобилии являются при возникающих и вновь повторяющихся обстоятельствах. Ведь многие поспешают к священнейшим церквам ради звания основателей $<$ церковных строений>, а после в этих же построенных <зданиях> они не прилагают дальнейшего стремления, и не выделяют на них достаточные расходы - и для возжигания светильников, и на священную службу, и на содержание тех, кто при них обретаются, - но оставляют их <церкви> пребывающими в <виде > голых строений и либо долженствующими быть разрушенными, либо частными <по отношению ко> всякой священной службе.

I. Следовательно, мы определяем, чтобы прежде всего было бы так, чтобы никому не дозволялось начинать строительство мо- настыря, или церкви, или молельни раньше, чем любезный Богу настоящий епископ <городской> общины на <этом> месте, явившись туда, и совершит молитвы, и публично установит крест, а также сделает <это> дело явным для всех. Ибо многие дурно заботятся о своих, разумеется, долженствующих быть построенными молельнях, чтобы они были поддержаны, в то время как плодятся строители не ортодоксальных церквей, но недопустимых пещер.

II. Далее, чтобы никто иначе не строил новую церковь прежде, чем поговорит с любезным Богу епископом, а также определит объем <того,> сколько он выделяет для возжигания светильников, и для священной службы, и для сохранения <этого священного> дома в исправности, и на содержание тех, кто там обретаются; и если только станет очевидным, что этого <объема> вполне достаточно, то $<$ пусть $>$ сначала он сделает дарение $<$ из $>$ тех $<$ средств $>$, которые должны быть ассигнованы, и так дом выстраивается. А если кто-то недостаточен для этого, но, возможно, охотится за званием, чтобы самому тоже называться основателем церкви, - то есть того, что он желает начать <строить, - то пусть знает, что $>$ и в этом царском Городе, и в провинциях есть многочисленные церкви, которые, впрочем, управляются достаточным образом, однако же опасность не в том, что они разрушаются от старости или же что они маленькие и украшены менее, чем хотелось бы тем, кто в них служат, а <в том, что> ему надлежит выбрать из такого рода церквей одну и завершить ее строительство, и чтобы при этом это дело также совершалось по совету милого Богу епископа православных. Ведь так и бывает у него, что он называется основателем священного <молельного> дома, а дополнительно ничего не издерживает из своего <имущества>, когда согласно обычаю на это дело предоставляются уже ассигнованные расходы теми, кто их изначально и предоставили.

$$
<\ldots>
$$

Дано в Константинополе, в календы мая, в 12-й год императора господина нашего Юстиниана, вечно Августа, в консульство светлейшего мужа Иоанна <то есть 1 мая 538 г.>. 


\section{ВИЗАНТИЙСКОЕ ПРАВОСЛАВИЕ}

(Данное уложение распространяет требование епископской молитвы перед началом строительства «молельни», что, по сути, означает храм, молитвенный дом, часовню или домовый храм. Ранее подобное требование было высказано только в отношении монастырей. Еще одно важное дополнение. Епископ должен публично установить крест. Публичность, как можно догадаться, расценивалась императором как способ заставить основателей и строителей церквей доводить начатое до конца; кроме того, публичность важна и для выявления еретичествующих («неортодоксальных») строителей, о существовании которых высказывает опасение император. Представляет интерес также предложение императора тем, кто хотел бы считаться «основателем церкви», но не имел достаточно средств на строительство и содержание храма, выбирать один из имевшихся во множестве недостроенных храмов и употреблять свои средства на завершение строительства и украшение оного.)

Nov. Just. 133: Автократор Юстиниан Август - Иоанну, славнейшему, во второй раз префекту святого претория Востока, бывшему (ординарному) консулу и патрикию,

«О монахах и монахинях, и их жизни».

$<\ldots>$

Ибо если имеются < пподобные> обиталища в каком-нибудь из монастырей под <управлением $>$ вселенского патриарха либо в этом великом Городе... или <из монастырей, > учрежденных на его территории, либо нами самими построенных, либо другими, в которых некоторые монахи имеют отдельное жилище, то ты все это всяческими способами уничтожишь и откроешь для них $<$ монахов $>$ взаимное между ними зрелище, дабы те, кто среди них проживают, наблюдали <друг за другом> все попеременно.

$<\ldots>$

Дано в Константинополе, в 17-й день перед календами апреля ... в консульство светлейшего мужа Апиона <то есть 16 марта 539 г.>.

Nov. Just. 131: Tот же василевс - Петру, славнейшему эпарху преториев,
«О церковных канонах и привилегиях». $<\ldots>$

VII. Если же кто-нибудь пожелает выстроить досточтимую молельню или монастырь, то приступит к строительству не иначе, как <после того, как> святейший епископ $<$ тех> мест совершит там молитву и установит досточтимый крест.

1. А кто вдруг примется либо устанавливать новую часовню, либо возобновлять старую, то всякими способами принуждается блаженнейшим епископом $<$ тех $>$ мест и его экономами, и гражданским <то есть городским> магистратом выполнить начатый труд либо сам, - если остается живым, - либо, по его смерти - <это сделают> его наследники.

VIII. Если кто-нибудь осмелится в своем доме - либо пригородном, либо <находящимся в отдаленном> поместье - отправлять церковную службу, то мы приказываем, чтобы его дом - как пригородный, так и деревенский, - где допущено что-то подобное, был виндицирован святейшей церкви $<$ того $>$ места через посредство любезнейшего Богу епископа, и его эконома, и местного гражданского магистрата.

$<\ldots>$

Х. Если же кто-нибудь примет решение в завещании, чтобы осуществилось строительство досточтимой молельни, или ксенодохии, или птохии, или орфанотрофии, или нозокомии, или иного досточтимого дома, то мы приказываем, чтобы молельня была сделана в течение пяти лет при попечении епископа $<$ тех> мест и гражданского (городского?) магистрата, а ксенодохия и птохия, или иной досточтимый дом <чтобы> появился в течение одного года.

1. Если же в течение года наследники не выполнят распоряжение завещателя о том, чтобы появилась ксенодохия или какой угодно досточтимый дом, то мы приказываем, чтобы они либо приобрели, либо арендовали дом, где могут быть исполнены распоряжения <завещателя>, пока дом такого рода возводится.

$<\ldots>$

XIV. $<\ldots>2$. А если какие-то из еретиков, к которым мы причисляем и несториан, и акефалов, и евтихиан, осмелятся выстроить пещеру своего безбожия, или же иудеи <по- 
желают> воздвигнуть новую синагогу, то святая церковь <тех> мест виндицирует <эти> постройки своему господству.

$<\ldots>$

Дано в Константинополе, в 15-й день перед календами апреля, в 18-й год господина нашего императора Юстиниана, вечно Августа, в 4-й год после консульства светлейшего мужа Василия, в 8-й индикт <то есть 16 марта 545 г.>.

(Здесь затрагивается одна из важнейших канонических проблем. Проведение богослужений в частных помещениях могло послужить основанием для отторжения данного недвижимого имущества в пользу Церкви.)

Nov. Just. 123: Tот же василевс - Петру, славнейшему магистру божественных оффикиев,

«О различных церковных вопросах»

(фрагмент в переводе К.А. Максимовича: $[4$, с. 38$]$.)

$<\ldots>$

XVIII. Если кто-либо построит молитвенный дом и захочет поставить в него клириков, если он сам или его наследники предоставят клирикам содержание и назовут достойных, то названные рукополагаются. $<$... >

$<\ldots>$

Дано в Константинополе, в календы мая, в 20-й год господина нашего императора Юстиниана, вечно Августа, в 5-й год после консульства светлейшего мужа Василия, в 11-й индикт <то есть 1 мая 546 г.>.

Как можно заметить, законодательство о церковном строительстве в исторический период после 534 г. количественно несколько продвинулось в сравнении с докодификационным периодом правления императора Юстиниана, что, впрочем, можно списать на разную протяженность времени каждого из этих периодов (в первом три прямых указания на строительство как явление охватываются временным промежутком с 528 по 530 г., тогда как фактическая продолжительность второго периода, в течение которого появились восемь новелл, в различной мере коснувшихся темы возведения церквей, ограничивается 535 и 546 гг.). По числу изданных конституций наибольшая активность законодателя в данном направлении приходится на два года - 528-й и 535-й, хотя в содержательном плане важнейшим следует признать 538 г., которым датирована новелла 67, в значительной степени посвященная строительству «молельных домов» и богоугодных заведений, точнее, - инициаторам этого строительства, так называемым ктиторам, и их правам и обязанностям в отношении возведенных зданий. Следовательно, уместно будет говорить не о постепенном количественном росте конституций, упоминающих строительство религиозных заведений как явление в жизни юстиниановского государства, а о приобретении эпизодически издаваемыми постановлениями такого рода в некий момент времени нового свойства, когда наряду с простой фиксацией факта строительной деятельности в них появляется описание деталей, что служит несомненным признаком становления законодательства о церковном строительстве как тематически особого раздела ранневизантийского права, а также перехода официального отношения к данному явлению на новый уровень (решающее значение в подготовке необычайно насыщенного информацией о строительстве текста 67-й новеллы Юстиниана имело, конечно же, завершение постройки Святой Софии в Константинополе в самом конце 537 г.).

Так, в конституциях 528-537 гг. основным классифицирующим тематическим признаком выступает едва ли не единственная фраза: «те, кто строят священные церкви», которая от закона к закону незначительно варьируется по содержанию (кроме церквей, объектом строительства называются монастыри и богоугодные заведения, а субъектом мог быть показан завещатель), но неизменна по смыслу (законодатель обнаруживает свое знание того, что церковные учреждения в стране возводятся, но его занимают другие события религиозной жизни, хотя и связанные отчасти с появлением новых церквей и монастырей). Редко воспроизводящий ее в тексте законов император явно не придает значения таким вопросам, как внешний вид и величина возводимого религиозного учреждения, стоимость строительства и источники его финансирования, плотность религиозной застройки на местах и даже в столице. Строительная тематика кажется третьестепенной по своему значению и, если такие вопросы и ставились 


\section{ВИЗАНТИЙСКОЕ ПРАВОСЛАВИЕ}

в указанный период времени, то, вероятно, решались мимоходом, параллельно с разрешением более насущных проблем, кстати, недвусмысленно обозначенных в церковном законодательстве Юстиниана.

Однако в конституции, опубликованной 1 мая 538 г. (новелла 67), «строительный» дискурс заметно усложняется. В ней признаком готовности императора к более внимательному рассмотрению названного явления выступает несколько загадочная фраза в прескрип-

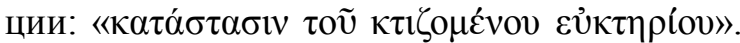
При этом смысл названия темы данной новеллы сомнений не вызывает, но именно приведенная фраза сообщает ему глубину, позволяя предполагать появление в сознании императора-законодателя более рельефной, чем прежде, картины процесса возведения «молитвенных домов», который получил у него

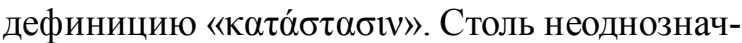
ный термин, продублированный в Аутентике не менее многозначным латинским словом «status», очевидно, должен был внушить заинтересованному читателю закона мысль о том, что дело, за которое он взялся в качестве ктитора, есть сложное и ответственное. В связи с этим выделенную нами фразу следует понимать именно в том смысле, что в правление Юстиниана Великого сформировался некий свод правил, описывающих порядок строительства церквей.

К сожалению, они не прописаны отдельно ни в одном из дошедших до нас документов юстиниановой эпохи. Однако законодательство императора Юстиниана содержит некоторые указания, которые можно рассматривать в качестве норм, принятых в сфере строительства зданий религиозного назначения. Они вполне типичны для времени становления официального «порядка» строительства, когда стихийно возникшее и либеральное по характеру явление постепенно проталкивалось верховной властью в создаваемые ею же рамки.

Судя по данным законодательства, наибольшую проблему в связи с частным строительством религиозных объектов для правительства Юстиниана представляло само бесконтрольное сооружение множества таких зданий (см., например: Nov. Just. 3; 6; 67; 131 [10, p. 18-24, 35-47, 344-347, 654-664]). Мaтериально готовые к этому делу подданные императора в массовом порядке стремились осуществить богоугодное и душеспасительное мероприятие, не задумываясь, вероятно, о действительной необходимости будущей местной церкви и об обеспечении постройки и службы в ней необходимым финансированием. В результате количество церквей, не ставших таковыми фактически, в стране заметно выросло, что потребовало от православных властей введения ограничительных мер. В новелле 67 все это неплохо описано. Создаваемые ею нормы ограничивали количество частного религиозного строительства [13, p. 40-43]. Юстиниан I, следовательно, не только не строил много религиозных объектов сам (в новеллах упоминание о построенных им монастырях встречается единожды Nov. Just. 133.I [10, p. 668]), но и вынужден был ограничивать соответствующую строительную активность частных лиц.

Другой проблемой того времени было возведение, несмотря на прежние многие запреты, своих храмов еретиками, иудеями и язычниками (например, Nov. Just. 131.XIV.2 $[10$, p. 663]). Примечательно, что ее решение осуществлялось в духе описанного выше отношения Юстиниана к практике частного строительства ортодоксальных церквей: последние запрещалось строить без соответствующего материального обеспечения и последующего достаточного снабжения, а если они все же были выстроены, то передавались в распоряжение местного епископа в качестве секулярных построек, - точно так же, как и молитвенные дома, возведенные религиозными диссидентами. Специальный юридический термин, который применялся для обозначения статуса передаваемых объектов - «виндикация» - не был изобретением hoc sub casu, но применялся в традиционном [1, с. 327], лишь несколько модернизированном вследствие появления нового участника гражданско-правовых отношений (то есть церкви) смысле. (О подобном приспосабливании императорской властью старых правовых институтов и понятий к новым условиям сосуществования церкви, общества и государства в специальной литературе уже говорилось; см., например: [8, с. 298]). Тем самым, Юстиниан I не преобразовывал молитвенные дома неверных в православные церкви и часовни и, соответ- 
ственно, не увеличивал с помощью них количество религиозных объектов в Империи. Принятые им в данной связи нормы способствовали увеличению в руках местных церковных организаций массы недвижимого имущества, распределяемого через сферу строительства.

Других проблем, сопрягаемых юстиниановским правительством со строительной практикой, в законодательстве 535-565 гг. не встречается. Таким образом, предполагаемая совокупность предписаний для сферы религиозного строительства, если таковая совокупность и сформировалась в более или менее собранном виде, в правление императора Юстиниана насчитывала немного пунктов, ни один из которых не может быть отнесен к регламенту технической стороны процесса строительства. При этом император наверняка четко представлял себе этапы этого процесса и не мог не знать о типичных трудностях, которые возникали перед строителями религиозных объектов, прежде всего церквей (Procop., De Aed. I.1.50 sqq.) [12, p. 28]. В таком случае очевидно, что они не являлись для него предметом, достойным упоминания в конституциях.

И все же в них можно обнаружить некие отголоски объемного представления Юстиниана I о строительстве церквей. Так, император Юстиниан выделял такие строительные этапы, как возведение «голого строения» (Nov. Just. 67.Pr.) [10, p. 344], и, вероятно, последующее создание специфического интерьера в готовом храме; различал типы религиозных строений (церковь, молельня, монастырь, богоугодные заведения), конечно, обладавших конструктивными особенностями; соотносил объем строительных работ с их продолжительностью и, вероятно, стоимостью (например, Nov. Just. 131.X [10, p. 658]; cp.: C.J. 1.3.45 (46) [9, p. 31-33]). Таким образом, Юстиниан признавал уже существовавшие в сфере строительства нормы и регламенты, соглашался с ними и не видел необходимости вводить новые взамен прежних или дополнительно к ним. Следовательно, в церковном строительстве вплоть до конца правления Юстиниана I продолжали господствовать давно выработанные общей строительной практикой технологические нормы и установки. Возникшая было потребность разработки регламента для сферы строительства религиозных заведений утратила актуальность и явно не была реализована.

Подведем общий итог предпринятого исследования.

Как и в первые годы самостоятельного правления Юстиниана I, прозванного Великим, церкви, монастыри и богоугодные заведения в Византийском государстве продолжали возникать и после 534 года. Законодательство императора свидетельствует как об этом, так и о том, что основным и массовым строителем названных объектов выступали частные лица (этот факт давно признан в историографии, хотя формально он не подкреплен полноценным анализом данных законодательства; см.: [2, с. 20-21; 11, p. 341]). При этом законодательный материал, имеющий отношение к теме религиозного строительства, претерпел некоторую эволюцию по сравнению с концом 20-х гг. VI в., продвинувшись и количественно, и содержательно, - от простого указания на факт существования такого строительства как явления до рассмотрения ряда обстоятельств, связанных с ним.

Однако ожидаемого появления регламента для сферы церковного строительства в юстиниановскую эпоху так и не произошло. Объективными основаниями для него должны было выступить рост частной строительной активности населения Империи и потребность кодифицировать имевшиеся отрасли римского права, которые испытывали воздействие изменявшейся жизни. Император Юстиниан отреагировал на вызовы современной ему действительности, однако его реформаторская деятельность применительно к сфере церковного строительства приобрела неожиданные формы, а именно: регламентации подвергся не сам строительный процесс, а активность частных донаторов строительства, что привело к появлению в законодательстве немногочисленных новых правил, к тому же не касавшихся технической стороны строительства. В связи с этим строительный процесс в VI в. сохранился в технологическом смысле в прежнем виде, не получив дополнительной дифференциации по отраслям строительства.

Императора Юстиниана нельзя назвать крупным частным ктитором, превосходившим 


\section{ВИЗАНТИЙСКОЕ ПРАВОСЛАВИЕ}

по объему личных финансовых вложений в строительство церквей или даже монастырей (к которым он, кажется, испытывал особую симпатию) известных благотворителей того времени. Несомненных данных об этом нет. В условиях же своеобразного бума частного строительства религиозных объектов в его правление император едва ли тратил на это и значительные государственные средства; по данным законодательства это также не прослеживается.

В течение всего времени правления Юстиниана I в большей мере интересовали в связи с религией проблемы, далекие от строительства как материального воплощения религиозных смыслов. Отвлечения носили конкретно-исторический характер (вроде ходатайства уважаемого локального предстоятеля или необходимости восстановить разрушенную стихией церковь по соседству с императорским дворцом). В связи с этим нельзя всерьез рассуждать и о существовании или хотя бы разработке некой «программы обширного церковного строительства в Империи» в 30-50-е гг. VI века.

\section{ПРИМЕЧАНИЯ}

${ }^{1}$ Серов Вадим Валентинович осуществил перевод оригинального источника, анализ историографии и подготовил текст статьи. Крейдун Юрий Александрович произвел редактирование текста статьи и снабдил комментариями переведенные фрагменты конституций Юстиниана.

\section{СПИСОК ЛИТЕРАТУРЫ}

1. Бартошек, М. Римское право: (Понятия, термины, определения) : пер. с чеш. / М. Бартошек. М. : Юрид. лит., 1989. - 448 с.

2. Левченко, М. В. Церковные имущества VVII вв. в Восточно-Римской империи / М. В. Левченко // Византийский временник. - 1949. - Т. 2. C. 11-59.

3. Максимович, К. А. Законодательство императора Юстиниана І о монашестве (часть 1) : новеллы V и LXXIX / К. А. Максимович // Вестник Православного Свято-Тихоновского гуманитарного университета. Серия I, Богословие. Философия. 2007. - Вып. 20. - С. 38-51.

4. Максимович, К. А. Новелла СХХІІІ св. императора Юстиниана I (527-565 гг.) «О различных церковных вопросах» (перевод и комментарий)
/ К. А. Максимович // Вестник Православного Свято-Тихоновского гуманитарного университета. Серия I, Богословие. Философия. - 2007. - Вып. 19. C. 22-54.

5. Максимович, К. А. Церковные новеллы св. императора Юстиниана I (527-565) в современном русском переводе: Из опыта работы над проектом / К. А. Максимович // Вестник Православного СвятоТихоновского гуманитарного университета. Серия I, Богословие. Философия. - 2007. - Вып. 17. -С. 27-44.

6. Морозов, М. А. Реформа ктиторского права в период правления Юстиниана / М. А. Морозов // Власть, политика, право в античности и средневековье : сб. ст. под ред. Е. П. Глушанина. - Барнаул : Изд-во Алтайского гос. ун-та, 2003. - С. 84-94.

7. Серов, В. В. Храмовое строительство в начальный период правления Юстиниана I (527534 гг.) / В. В. Серов, Ю. А. Крейдун // Вестник Волгоградского государственного университета. Серия 4, История. Регионоведение. Международные отношения. - 2016. - Т. 21, № 5. - C. 113-120. - DOI: https://doi.org/10.15688/jvolsu4.2016.5.10.

8. Соколов, П. Н. Церковно-имущественное право в Греко-Римской церкви : Опыт историко-юридического исследования / П. Н. Соколов. - Новгород : Паровая тип. И. И. Игнатовского, 1896. - 300 с.

9. Corpus Iuris Civilis. Vol. II. Codex Iustinianus / Rec. P. Krueger. - Berlin : apud Weidmannos, 1906. XXX, 513 p.

10. Corpus Iuris Civilis. Vol. III. Novellae/Rec. R. Schoell et G. Kroll. - Berolini : apud Weidmannos, 1954. - XXIII, 813 p.

11. Jones, A. H. M. Church Finance in the Fifth and Sixth Centuries / A. H. M. Jones // The Roman Economy. Studies in Ancient Economic and Administrative History /A. H. M. Jones; ed. byP. A. Brunt. - Oxford : Blackwell, 1974.-P.339-349.

12. Procop. Werke. Bd. 5. Procop. Bauten / griechisch-deutsch ed. von Otto Veh. - München : Heimeran, 1977. - 571 p.

13. Thomas, J. Ph. Private Religious Foundations in the Byzantine Empire / J. Ph. Thomas. Washington : Dumbarton Oaks Research Libr. and Coll., 1987.-XIV, 308 p.

\section{REFERENCES}

1. Bartoshek M. Rimskoe pravo: (Ponyatiya, terminy, opredeleniya) [Roman Law: (Concepts, Terms, Definitions)]. Moscow, Yurid. lit., 1989. 448 p.

2. Levchenko M.V. Tserkovnye imushchestva V-VII vv. v Vostochno-Rimskoy imperii [Church Properties in the East Roman Empire in the $5^{\text {th }}-7^{\text {th }}$ Centuries]. Vizantiyskiy vremennik [Byzantina Xronika], 1949, vol. 2, pp. 11-59. 
3. Maksimovich K.A. Zakonodatelstvo imperatora Yustiniana I o monashestve (chast 1) : novelly V i LXXIX [Legislation of Justinian I about Monasticism (Part 1): Novels V and LXXIX]. Vestnik Pravoslavnogo SvyatoTikhonovskogo gumanitarnogo universiteta. Seriya I, Bogoslovie. Filosofiya, 2007, vol. 20, pp. 38-51.

4. Maksimovich K.A. Novella CXXIII sv. imperatora Yustiniana I (527-565 gg.) “O razlichnykh tserkovnykh voprosakh" (perevod i kommentariy) [Novel CXXIII of Justinian the Emperor (527-565) “On Different Church Issues" (Translation in Russian with Commentary)]. Vestnik Pravoslavnogo SvyatoTikhonovskogo gumanitarnogo universiteta. Seriya I, Bogoslovie. Filosofiya, 2007, vol. 19, pp. 22-54.

5. Maksimovich K.A. Tserkovnye novelly sv. imperatora Yustiniana I (527-565) v sovremennom russkom perevode: Iz opyta raboty nad proektom [Church Novels of Justinian I the Emperor (527-565) in the Modern Translation into Russian: from the Experience of Work on the Project]. Vestnik Pravoslavnogo Svyato-Tikhonovskogo gumanitarnogo universiteta. Seriya I, Bogoslovie. Filosofiya, 2007, vol. 17, pp. 27-44.

6. Morozov M.A. Reforma ktitorskogo prava $\mathrm{v}$ period pravleniya Yustiniana [The Justinian's Reform of the Ktitor Law]. Glushanin E.P., ed. Vlast, politika, pravo $v$ antichnosti i srednevekovye: sb. st. Barnaul, Izd-vo Altayskogo gos. un-ta, 2003, pp. 84-94.

7. Serov V.V., Kreydun Yu.A. Khramovoe stroitelstvo $\mathrm{v}$ nachalnyy period pravleniya Yustiniana
I (527-534 gg.) [Church Building in the Early Justinian's Rule (527-534)]. Vestnik Volgogradskogo gosudarstvennogo universiteta. Seriya 4, Istoriya. Regionovedenie. Mezhdunarodnye otnosheniya [Science Journal of Volgograd State University. History. Area Studies. International Relations], 2016, vol. 21, pp. 113-120. DOI: https://doi.org/10.15688/ jvolsu4.2016.5.10.

8. Sokolov P.N. Tserkovno-imushchestvennoe pravo v Greko-Rimskoy tserkvi: Opyt istorikoyuridicheskogo issledovaniya [Church-Property Law in the Byzantium (Greek-Roman Church): Experience of Historical and Legal Research]. Novgorod, Parovaya tip. I. I. Ignatovskogo, 1896. 300 p.

9. Krueger P., ed. Corpus Iuris Civilis. Vol. II. Codex Iustinianus. Berlin, apud Weidmannos, 1906. $\mathrm{xxx}, 513 \mathrm{p}$.

10. Schöll R., Kroll G., eds. Corpus Iuris Civilis. Vol. III. Novellae. Berlin, apud Weidmannos, 1954. xxiii, $813 \mathrm{p}$.

11. Jones A.H.M. Church Finance in the Fifth and Sixth Centuries. Brunt P.A., ed. The Roman Economy: Studies in Ancient Economic and Administrative History. Oxford, Blackwell, 1974, pp. 339-349.

12. Veh O., ed. Procop. Werke. Bd. 5. Procop. Bauten. München, Heimeran, 1977. 571 p.

13. Thomas J.Ph. Private Religious Foundations in the Byzantine Empire. Washington, Dumbarton Oaks Research Libr. and Coll., 1987. xiv, 308 p.

\section{Information about the Authors}

Yuriy A. Kreydun, Doctor of Arts, Vice-Rector, Barnaul Theological College, Lazurnaya St., 1-13, 656006 Barnaul, Russian Federation, krey70@mail.ru, https://orcid.org/0000-0002-0746-8875

Vadim V. Serov, Doctor of Sciences (History), Associate Professor, Professor of Department of State and Law, Altay Institute of Economics, Branch of Saint Petersburg University of Management Technologies and Economics, Prosp. Lenina, 106e, 656011 Barnaul, Russian Federation, wseroff@yandex.ru, https://orcid.org/0000-0003-0348-5499

\section{Информация об авторах}

Юрий Александрович Крейдун, доктор искусствоведения, проректор по учебной части, Барнаульская духовная семинария, ул. Лазурная, 1-13, 656006 г. Барнаул, Российская Федерация, krey70@mail.ru, https://orcid.org/0000-0002-0746-8875

Вадим Валентинович Серов, доктор исторических наук, доцент, профессор кафедры государственно-правоведческих дисциплин, Алтайский институт экономики (филиал) Санкт-Петербургского университета технологий управления и экономики, просп. Ленина, 106e, 656011 г. Барнаул, Российская Федерация, wseroff@yandex.ru, https://orcid.org/0000-0003-0348-5499 